\title{
GAMBARAN TINGKAT PENGETAHUAN REMAJA TENTANG PMS DI SMK MAHARDIKA SURABAYA
}

\author{
Intiyaswati* \\ STIKes William Booth SurabayaJl.Cimanuk No.20 Surabaya 60241 \\ intiyaswati21@gmail.com
}

\begin{abstract}
ABSTRAK
Penyakit menular seksual mencerminkan definisi setiap mikroba yang ditularkan seseorang kepada orang lain melalui kontak yang dekat dan intim (spense). Dewasa ini kehidupan seks bebas telah merambat kekalangan kehidupan remaja sehingga banyak remaja yang terjangkit penyakit menular seksual dimana masa remaja adalah masa transisi antara masa kanak - kanak dengan dewasa dan relatif belum mencapai tahap kematangan mental dan sosial dengan adanya rasa ingin tahu yang tinggi remaja cenderung ingin mencoba tanpa didasari dengan pengetahuan yang cukup. Penelitian ini menggunakan desain penelitian 'Deskriktif". Tujuan penulis karya tulis ilmiah ini adalah untuk mengidentifikasi gambaran tingkat pengetahuan remaja tentang penyakit menular seksual. Populasi yang di ambil adalah seluruh siswa - siswi SMK Mahardika Surabaya sejumlah 920 dan sampel 282 orang yang memenuhi kriteria. Metode sampling yang digunakan adalah Simpel Random. Data dikumpulkan dengan kuisioner. Hasil penelitian ini antara lain adalah pengetahuan remaja tentang PMS di SMK Mahardika Surabaya sebagian responden memiliki pengetahuan baik tentang PMS (Penyakit Menular Seksual) yaitu 150 orang (53\%), yang berpengetahuan cukup sebanyak 111 orang (39\%) dan yang terkecil responden berpengetahuan kurang sebanyak 20 orang (8\%). Dari hasil penelitian ini dapat disimpulkan gambaran tingkat pengetahuan remaja tentang PMS di SMK Mahardika Surabaya sebagian memiliki tingkat pengetahuan baik yaitu 150 orang (53\%). Oleh karena itu, diharapkan remaja yang sudah memiliki pengetahuan baik dapat mensosialisasikan kepada teman - temannya yang berpengetahuan cukup dan kurang dengan didampingi oleh guru atau tim kesehatan.
\end{abstract}

\section{Kata kunci : Pengetahuan, Remaja dan PMS (Penyakit Menular Seksual)}

\begin{abstract}
Sexually transmitted diseases reflect definitions of each microbe that is transmitted one person to another through close contact and intimate (spense). This adult sex life has crept up to teenage life that many teenagers who contracted a sexually transmitted disease where Adolescence is a period of transition between childhood and the adult relative has not reached the stage of mental and social maturity in the presence of a high curiosity teens tend to want to try without constituted with enough knowledge. This study use descriptive research design. The purpose of this study is to identify level of knowledge of adolescents about sexually transmitted diseases. Population that is taken is all students of SMK Mahardika Surabaya which total is 920 students and 282 students that met the criteria. The sampling method used is simple random. Data were collected by questionnaire. Results of this study is adolescents Mahardika SMK Surabaya majority of respondents had a good knowledge about Sexually transmitted diseases,
\end{abstract}


that 150 people (53\%), sufficient knowledge as many as 111 people (39\%) and the less knowledge respondents as many as 20 people $(8 \%)$. From these results we can concluded that that the level of knowledge about Sexually transmitted diseases in adolescents SMK Surabaya Mahardika most have a good knowledge of 150 people $(53 \%)$. We expected adolescents who already have a good knowledge to disseminate to friends who is sufficient knowledge and less with accompanied by a teacher or healthcare team.

Key words : knowledge, Teenage, and Sexually transmitted diseases 


\section{PENDAHULUAN}

Dewasa ini kehidupan seks bebas telah merambat kekalangan kehidupan remaja dan anak sehingga pendidikan seks bebas atau pendidikan mengenai kesehatan reproduksi yang lebih trendnya sex education sudah seharusnya diberikan kepada anak - anak yang sudah beranjak dewasa atau remaja baik melalui pendidikan formal maupun informal. Masa remaja adalah masa transisi antara masa kanak - kanak dengan dewasa dan relative belum mencapai tahap kematangan mental dan sosial sehingga mereka harus menghadapi tekanan- tekanan emosi dan sosial yang saling bertentangan. Pengaruh informasi global yang semakin mudah diakses justru memancing anak dan remaja untuk mengadaptasi kebiasaan kebiasaan tidak sehat seperti merokok, minum- minuman berakohol, penyalahgunaan obat terlarang dan suntikan terlarang perkelahian antara remaja dan seks bebas (Syarif, 2008).

Penyakit menular seksual sampai sekarang ini, masih menjadi masalah kesehatan, sosial maupun ekonomi diberbagai negara yang ditularkan melalui hubungan seksual (WHO, 2003). Di Amerika Serikat insiden PMS merupakan penyakit yang paling banyak ditemukan pada kalangan remaja hampir 70\% remaja di negara ini terjangkit PMS akibat pergaulan yang membebaskan seks bebas ditemukan gonore sebesar $57,7 \%$ dan candidiasis $23 \%$, lebih parah lagi di kota New York hampir sebagian besar anak remaja pernah menderita PMS dan di Indonesia sebanyak $38,9 \%$, sebesar $10,2 \%$ pada vaginosis bacterial, 9,1\% pada kandidas, 3,4\% pada gonore, $1,1, \%$ pada trikomoniasis dan $1,11 \%$ pada gonorea bacteri trikomoniasis. Prevelensi penyakit menular seksual di Indonesia yang ditemukan dibeberapa kota, khususnya dikota Surabaya yang mendapat peringkat ke 2 yang memiliki insiden PMS paling banyak setelah kota bali, penyakit menular seksual yang ditemukan antara lain chlamidya sebesar $33,7 \%$ syphilis $28,8 \%$ dan gonorrea 19,8\% (Rauf, 2008).

Pengetahuan tentang infeksi menular seksual dapat ditingkatkan dengan pemberian pendidikan kesehatan reproduksi yang dimulai pada usia remaja. Pendidikan kesehatan reproduksi di kalangan remaja bukan hanya memberikan pengetahuan tentang organ reproduksi, tetapi juga mengenai bahaya akibat pergaulan bebas, seperti penyakit menular seksual dan kehamilan yang belum diharapkan atau kehamilan berisiko tinggi (BKKBN, 2005). Dibeberapa Negara anatara lain Amerika Serikat, New York, Afrika disebutkan bahwa pelaksanaan program penyuluhan yang intensifikan menurunkan insidiens penyakit menular seksual atau paling tidak insidiensnya relatip tetap. Namun demikian, di sebagian besar negara insidiensnya penyakit menular seksual relative masih tinggi (Hakim, 2003). Berdasarkan gambaran yang terjadi maka perlu dilakukan penelitian untuk mendapatkan bagaimana tingkat pengetahuan remaja terhadap penyakit menular seksual khususnya di SMK Mahardika Surabaya sebagai tempat penelitian agar dapat diketahui apakah di SMK Mahardika Surabaya diperlukan tambahan pendidikan kesehatan reproduksi bagi remaja agar mereka mengetahui bahaya bergonta ganti pasangan yang adanya hubungan seksual pranikah atau di luar nikah dalam upaya menghambat tingginya peningkatan insidens penyakit menular seksual di kalangan remaja dewasa ini.

\section{METODE}

Metode Penelitian ini menggunakan metode diskriktif yaitu metode penelitian yang dilakukan dengan tujuan utama untuk membuat gambaran atau deskripsi tentang suatu keadaan secara obyektif. Pengambilan data dengan menggunakan data primer yang diperoleh dari hasil kuesioner. 
Pada penelitian ini populasinya adalah seluruh siswa-siswi pada SMK Mahardika Surabaya 960 orang. Teknik sampling yang digunakan dalam penelitian ini adalah simple random sampling dengan pengundian populasi secara acak sehingga setiap anggota dalam populasi memiliki kesempatan yang sama. Penelitian ini menggunakan kuesioner sebagai intrumen. Pengolahan data dilakukan dengan cara : editing, coding, tabulating, scoring.

\section{HASIL}

Data umum ini menggambarkan tentang karateristik responden berdasarkan usia, jenis kelamin, dan Tingkat Dalam Sekolah

\subsection{Distribusi Frekuensi Responden}

\section{Berdasarkan Umur}

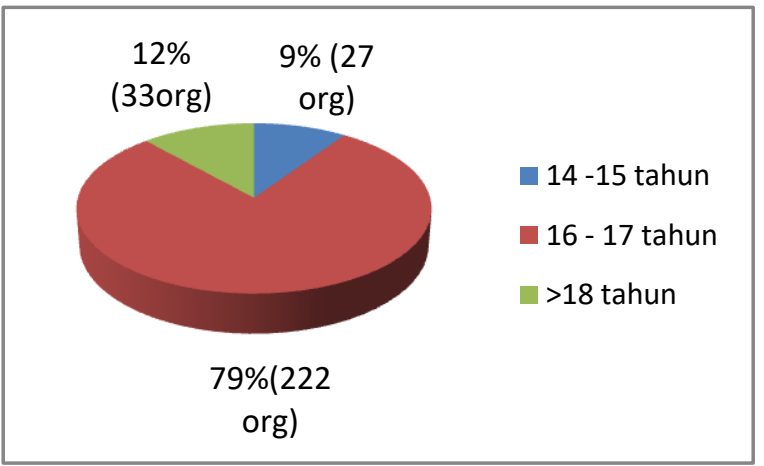

Gambar 1.1 Diagram Pie Distribusi Frekuensi Responden Berdasarkan Umur Di

SMK Mahardika Surabaya pada bulan November 2018

Berdasarkan data di atas diketahui bahwa sebagian besar responden berusia 16 - 17 tahun yaitu sebanyak $79 \%$.

Distribusi Frekuensi Responden Berdasarkan Jenis Kelamin

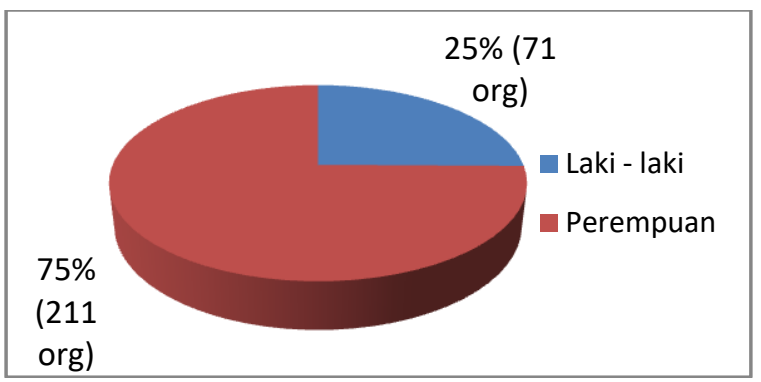

Gambar 1.2 Diagram Pie Distribusi

Frekuensi Responden Berdasarkan Jenis Kelamin Di SMK Mahardika Surabaya pada bulan November 2018

Berdasarkan data di atas diketahui bahwa sebagian besar responden berjenis kelamin perempuan yaitu $75 \%$ remaja di smk mahardika berjenis kelamin perempuan Distribusi Frekuensi Responden Berdasarkan Tingkat Dalam Sekolah

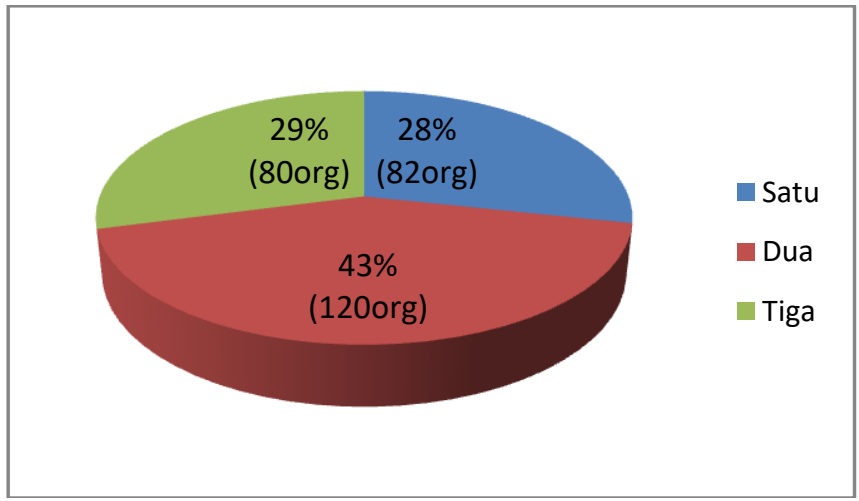

Gambar 1.3 Diagram Pie Distribusi Frekuensi Responden Berdasarkan Tingkat

Dalam Sekolah Di SMK Mahardika

Surabaya pada bulan November 2018

Berdasarkan data diatas dapat diketahui bahwa terbanyak responden adalah kelas 2 yaitu $43 \%$.

\section{Data Khusus}

Data khusus ini menggambarkan gambaran tingkat pengetahuan remaja tentang PMS Di SMK Mahardika Surabaya

\subsection{Distribusi Frekuensi Responden Berdasarkan Tingkat Pengetahuan}


Gambar 1.1 Diagram Pie Tingkat Pengetahuan Remaja tentang

PMS di SMK Mahardika Surabaya pada

Bulan November 2018.

Berdasarkan gambar 4.4 menunjukan sebagian responden memiliki tingkat pengetahuan baik tentang PMS yaitu 150 orang $(53 \%)$.

\section{Pembahasan}

Pada pembahasan ini akan diuraikan hasil penelitian mengenai gambaran tingkat pengetahuan remaja tentang PMS di SMK Mahardika Surabaya.

\section{Tentang karateristik responden} Berdasarkan umur

Didapatkan terbanyak umur 16 - 17 tahun yaitu sebanyak 222 orang $(79 \%)$ responden. Menurut Notoadmojo (2003) mengatakan bahwa semakin bertambahnya usia seseorang, semakin tinggi kematangan dalam berfikir dan semakin bertambahnya usia seseorang semakin dapat menggunakan koping yang adaptif. Hal ini dapat diartikan bahwa karateristik usia responden usia 16 17 tahun adalah usia dimana remaja menginjak usia pubertas dan perlahan memasuki usia dewasa awal sehingga pengetahuan yang didapat baik pengetahuan formal melalui pendidikan maupun pendidikan nonformal bisa di aplikasikan dalam kehidupannya. Hasil penelitian menunjukan 18 orang $(6,3 \%)$ mempunyai pengetahuan cukup dengan usia 14 - 15 tahun, usia 18 tahun berpengetahuan kurang. Salah satu faktor yang mempengaruhi pengetahuan adalah usia dimana pada usia tertentu seseorang mengalami penurunan kemampuan dalam mencerna informasi yang diterima semakin baik seseorang menerima informasi maka semakin baik pula tingkat pengetahuan. Tetapi dari hasil penelitian menunjukan bahwa usia muda justru berpengetahuan kurang yaitu usia $>18$ tahun. Sedangakn usia $16-17$ tahun berpengetahuan baik. Hal ini mungkin karena mereka ketika mengikuti penyuluhan yang di adakan ketika disekolah mereka kurang mendengarkan dan mereka kurang suka membaca.

\section{Karateristik responden Berdasarkan jenis kelamin}

Didapatkan terbanyak jenis kelamin perempuan yaitu sebanyak 211 Orang (75\%) responden. Menurut Notoadmojo (2003) mengatakan bahwa perbedaan jenis kelamin telah dikodratkan oleh Tuhan, oleh sebab itu bersifat permanen, perbedaan antara laki laki dan perempuan tidak sekedar bersifat biologis akan tetapi aspek sosial, kultural. Karateristik jenis kelamin dengan gambaran tingkat pengetahuan tentang PMS erat sekali dengan remaja puteri lebih banyak remaja putri memiliki pengetahuan yang baik dikarenakan pada remaja putri lebih sering memanfaatkan fasilitas yang ada pada sekolah sepertih halnya perpustakaan dan remaja putri lebih sering atau lebih gemar untuk membaca, hal ini terbukti dari hasil survei yang saya lakukan diperpustakaan SMK Mahardika bahwa yang lebih banyak hadir adalah remaja putri yang memanfaatkan salah satu fasilitas sekolah ini.

\section{Kareteristik responden Berdasarkan tingkat dalam sekolah}

Didapat terbanyak tingkat dalam sekolah kelas 2 yaitu sebanyak 120 orang (43\%) responden. Menurut Notoatmojo (2003), semakin tinggi pendidikan semakin mudah untuk menerima informasi sehingga semakin banyak pengetahuan yang didapat. Sebaliknya pendidikan yang kurang akan menghambat perkembangan sikap seseorang terhadap nilai - nilai baru yang diperkenalkan. Hal ini menunjukan semakin tinggi tingkat dalam sekolah semakin baik kemampuan untuk menyerap dan memahami suatu informasi. Hasil dari penelitian menunjukan sebanyak 100 orang (49\%)yang memiliki pengetahuan baik adalah siswa siswi kelas 2, hal ini bertentangan pada teori 
yang telah di kemumakan oleh Notoatmojo bahwa semakin tinggi tingkat yang ada di sekolah semakin baik pula pengetahuannya pada lapangan bertentangan dengan apa yang di kemumakan oleh notoatmojo di karenakan pada saat ada penyuluhan disekolah yang lebih banyak hadir adalah siswi kelas 2, dan siswi kelas 2 lebih banyak memanfaatkan fasilitas sekolah yaitu perpustakaan dan pada siswi kelas 3 banyak yang melakukan PKL (Praktek Kerja Lapangan).

4 tentang gambaran tingkat pengetahuan remaja tentang PMS di SMK Mahardika surabaya sebagian responden memiliki pengetahuan baik tentang PMS (Penyakit Menular Seksual) yaitu 150 orang (53\%), yang berpengetahuan cukup sebanyak 111 orang $(39 \%)$ dan yang terkecil responden berpengetahuan kurang sebanyak 20 orang (8\%). Menurut Notoatmojo (2003) pengetahuan merupakan hasil tahu yang terjadi setelah seseorang melakukan pengideraan terhadap suatu objek tertentu. Pengetahuan dipengaruhi oleh usia, lingkungan, pendidikan, agama dan sosial ekonomi. Menurut John Hill yang dikutip oleh Pardede (2002), pada perubahan kognitif perlu adanya informasi, pengetahuan reproduksi, kebersihan kulit, narkoba dan penyakit seksual. Dalam hal ini faktor - faktor tersebut tidak selalu mutlak dapat mempengaruhi tingkat pengetahuan seseorang karena setiap individu memiliki kemampuan menerima informasi, pengalaman yang berbeda, dan kesempatan yang tidak sama, sehingga dalam penelitian ini banyak remaja yang memiliki tingkat dalam sekolah semakin tinggi tetapi memiliki pengetahuan yang kurang dapat disebabkan kurangnya pengetahuan anak kelas 3 karena sibuknya anak kelas 3 mengikuti PKL dan kurang mengikuti penyuluhan sedangkan yang memiliki pengetahuan baik adalah yang bertingkat kelas 2 dikarenakan pada anak kelas 2 memiliki waktu senggang yang lebih banyak sehingga banyak anak kelas 2 yang mengikuti penyuluhan, seringnya anak kelas 2 yang mengunjungi perpustakaan dan yang memiliki pengetahuan yang cukup kemungkinan mereka tidak memanfaat kan fasilitas yang ada dan kurangnya dalam penerimaan materi ketika diadakan penyuluhan. Perlu ditekankan bahwa bukan berati seseorang yang berpendidikan rendah mutlak pengetahuannya akan rendah pula karena peningkatan pengetahuan tidak hanya diperoleh dipendidikan formal akan tetapi dipendidikan non formal juga dapat diperoleh seperti halnya membaca buku, menonton televisi atau informasi dari teman atau orang lain.

\section{Simpulan}

Berdasarkan analisis data dan penelitian yang telah dilakukan maka dapat disimpulkan bahwa gambaran tingkat pengetahuan remaja tentang PMS di SMK Mahardika surabaya sebagian memiliki tingkat pengetahuan baik yaitu 150 orang $(53 \%)$.

\section{Saran}

Saran yang diberikan oleh peneliti berdasarkan kesimpulan adalah sebagai berikut :

\section{Bagi SMK Mahardika Surabaya}

Hendaknya remaja yang sudah memiliki pengetahuan baik dapat mensosialisasikan kepada teman - temannya yang berpengetahuan cukup dan kurang dengan didampingi oleh guru atau tim kesehatan.

2 Diharapkan pihak sekolah lebih sering mengadakan penyuluhan kesehatan yang berhubungan dengan topik PMS (Penyakit Menular Seksual)/kesehatan reproduksi.

Diharapkan bagi orang tua murid dapat mengawasi kebiasan - kebiasaan anak sehingga kebiasaan - kebiasan buruk yang dapat menyebabkan PMS dapat di cegah dan tidak lupa memberikan pengetahuan kepada si anak yang berhubungan dengan topik PMS. Diharapkan pula orangtua tetap 
berkoordinasi dan melakukan komunikasi dengan pihak sekolah dan guru BK (Bimbingan Konseling).

3. Bagi Institusi STIKES William Booth Diharapkan kampus dapat menambah refrensi buku tentang PMS di perpustakaan sehingga dapat menambah pengetahuan tentang PMS untuk mahasiswa dan mahasiswi di Stikes William Booth surabaya.

4. Bagi Peneliti Selanjutnya

Diharapkan untuk peneliti selanjutnya dapat memberikan informasi yang lebih jelas tentang PMS, sebagai bahan pertimbangan di dalam melakukan peneliti lebih lanjut dengan faktor - faktor yang belum dikembangkan, terutama yang berhubungan dengan kesehatan reproduksi.

\section{DAFTAR PUSTAKA}

Benson, Ralph C. 2008. Buku Saku Obsterti dan Genekologi. Jakarta : EGC

Bobak. 2004. Buku Ajar Keperawatan Maternitas. Jakarta : EGC

Citra, Foezi. 2012. Mahir menjaga organ intim wanita. Solo: Tinta Medika

Heffner, linday dan Danny J schusct. 2006. At a Gance Sistem Reproduksi. Jakarta: Erlangga
Kusmiran, Eny. 2011. Kesehatan Reproduksi Remaja dan Wanita. Jakarta: Salemba Medika

Manuaba, dkk. 2011. Kesehatan Reproduksi untuk Mahasiswa Bidan. Jakarta: EGC

Mira W, Dwi. 2009. Buku Ajar Biologi Reproduksi. Jakarta: EGC

Notoatmojo, soekarno. 2003. Konsep \& Dasar Penerapan Metodologi Penelitian Ilmu Keperawatan Pedoman Skripsi, Tesis dan Istrumen Penelitian Keperawatan. Jakarta : Salemba Medika

Nursalam. 2003. Konsep Dasar dan Penulisan Riset Keperawatan. Yogyakarta: Graha Ilmu

Prawiharjo, Sarwono. 2009. Ilmu kebidanan. Jakarta : PT. Bina Pustaka Sarwono Prawiharjo

Setiadi. 2007. Konsep Dasar dan Penelitian Riset Keperawatan. Yogyakarta: Graha Ilmu

Sinclair, lonstante. 2009. Buku Saku Kebidanan. Jakarta: EGC

Windhu, Siti Chandra. 2009. Disfungsi Seksual Tinjauan Fisiologis dan Patologis Terhadap Seksualitas. Yogyakarta: Andi 